\title{
Pre Instructional Design for Academic Writing in Digital Era
}

\author{
Lili Perpisa ${ }^{1}$, M. Zaim² ${ }^{2}$ Mukhaiyar ${ }^{3}$, and Ahmad Fauzan ${ }^{4}$ \\ ${ }^{1}$ Doctoral Students of Universitas Negeri Padang, Padang, Indonesia, liliperpisa@ gmail.com \\ ${ }^{2}$ Universitas Negeri Padang, Padang,Indonesia,mzaim_unp@yahoo.com \\ ${ }^{3}$ Universitas Negeri Padang, Padang, Indonesia, jmukhaiyar@yahoo.com \\ ${ }^{4}$ Universitas Negeri Padang, Padang, Indonesia, ahmad.zan66@gmail.com
}

\begin{abstract}
In competitive era to produce high quality of learning outcome, educators should be creative and innovative in designing learning instructional. They are as answers what the students need. Domain of teaching writing has been touched by online writing instruction (technology-enabled learning environment). A study, interviewing the students need toward online writing, showed that the students need out of class space to write. Classroom atmosphere is not enough for them to finish their writing. Internet as close part in their activity should be take important part in their learning process. They also argue that currently material teaching to support their writing is needed. This study design of blended learning for academic writing by proportion of content delivered online $30 \%$ of 16 meetings. It covered pre-writing,drafting, revising and editing, re-writing and assessing.
\end{abstract}

Keywords: Instructional Design, online learning, academic writing.

\section{INTRODUCTION}

Rapidly development of technology demand teaching academic writing not only by face to face, but also enabling technology environment. It is as a effort to improve students ability in writing. Computer as means to write, deliver, and accept learning information (Barker, 2000). The students may use e-mail, power point, screen, online discussion to consult their task and writing (Peretz, 2005). Mobile phone as alternative to apply Mobile Assisted Language Learning (MALL) that can bring easily to everywhere (Zaki and Yunus, 2015). Then, Massive Open Online Learning Courses (MOOCs) acted as platforms in teaching academic writing which proved positive motivation on students writing. During online learning, the students have a free in learning and they believe that they do better. This form has time and place flexibility.

Online writing provides wide opportunity for students to produce good writing. They may write and revise their writing while in or out of class. They also keep contact with lecturer in giving her/his feedback anywhere and anytime. This design is believed to be able to accommodate teaching learning academic writing process. In Moodle form, teacher uploads an article for error analysis. Then proceed to the writing process by giving visuals to students, so they give feedback on what they see. Every week, the teacher asses their work (Adas and Bakir, 2013). This process helps students ability in writing.

In University level at Sumatera Barat, online learning on academic writing has not received a positive response since there are regulations for mandatory face-toface meetings in 16 times. Online process is not categorized as formal meeting. The use of e-mails, edmodo, blogs are only limited to placing teaching material and sending assignments. While writing activity, like determining topics, revising, editing, giving feedback, and evaluating are done traditionally. Time and place in conducting writing are not enough and comfort. As result, their capability to produce writing academic tends to be low. By analyzing the facts, the problems in this study are identified; (1) limited time in academic writing classes makes students unable to pass the writing process perfectly, (2) Lack of feedback from classmates and lecturers to improve their writing. (3) The use of email in sending assignments has not been able to help the teaching process of academic writing, (4) The evaluation process conducted by lecturers only be done in the final process. So, we need a learning model that provide opportunities for students to make academic writing as the writing process itself. Likewise,the lecturer provide feedback and make appropriate evaluations in order to improve students' academic writing skills. Therefore, in this study, researchers would design instructional for academic writing based on students need.

\section{METHOD}

To collect the data, this study did interview to 20 students who take academic writing class in English Department of STKIP PGRI Sumatera Barat. The questions explore students' needs for online learning. It consisted 14 questions. Based on the students answer, the researcher 
designed Pre Instructional Design for academic writing. The process of this study is a part of Research Design which put forward Plomp \& Nieveen (2013) thought because it would design, develop a product such as a program, model, teaching material, teaching and learning strategy, material and media as a solution to the problem occurs. This research intends to produce a product, a new theory, which can regulate the teaching and learning process. In this case, it focused on designing instructional design of academic writing based on students need.

\section{RESULTS AND DISCUSSION}

The instructional design of academic writing based on students respond on interviewing activity. The table 1 shows that how the students need on online learning.

Table. 1 Students Need

\begin{tabular}{|l|l|}
\hline Statement & Most Students Respon \\
\hline $\begin{array}{l}\text { Proportion of online } \\
\text { learning }\end{array}$ & $31-50 \%$ \\
\hline Writing Topic & $\begin{array}{l}\text { Teaching English, } \\
\text { Literature, } \\
\text { Lingustics }\end{array}$ \\
\hline Online Tool & Web \\
\hline Learning Material & $\begin{array}{l}\text { Choosing the topic, Review } \\
\text { article, Paraphrasing, } \\
\text { Summarizing, References, } \\
\text { Editing, Revising, mendeley }\end{array}$ \\
\hline Comfort place for writing & $\begin{array}{l}\text { Campus (2 students) } \\
\text { Labor (none) } \\
\text { Home (all) } \\
\text { Others; baech, cafe (6 } \\
\text { Students) }\end{array}$ \\
\hline $\begin{array}{l}\text { Lecturer way to deliver } \\
\text { teaching Material }\end{array}$ & Face to Face and Online \\
\hline $\begin{array}{l}\text { Synchronous } \\
\text { communication }\end{array}$ & 3 students need \\
\hline $\begin{array}{l}\text { UnSynchronous } \\
\text { Communication }\end{array}$ & All Students need \\
\hline Internet in classroom & All students need \\
\hline $\begin{array}{l}\text { Revising and Editing } \\
\text { Process }\end{array}$ & $\begin{array}{l}\text { Do together with friends } \\
\text { and lecturer }\end{array}$ \\
\hline Collecting the writing task & By online \\
\hline
\end{tabular}

First question related to students expectation to be conducted in online. 2 of 20 students responded need online learning less than $30 \%$ and a student needed more than $80 \%$. 18 students answered $31-79 \%$ or $5-8$ meetings. It declares that students need a blended learning to accommodate them by 2 learning model, are; traditional model to interact directly and technology environment model (Lalima \& Dangwal, 2017). In traditional model, they students can discuss about all material directly. Then, in online learning, the student may then, topic of writing. They claimed that all topics about teaching English are needed. A students added management in learning as alternative topic for writing.

Next question about tools for online learning. They have varied answers. 7 students chose moodle, e-mail, blog, and web. Designing web as the majority choice since all students thought it was a important in learning. It is believed that web enhance students motivation in learning English and it also presents appropriate and authentic learning material (Atmanegara, Agustina, Tiara, 2013). Then, teaching material needed. There ignored two materials since they have already learnt in previous semester, they are; writing main idea and writing supporting ideas. Meanwhile, material about choosing the topic, review the article, paraphrase, summarize, reference, edit, revise are needed. They also needed knowledge about how to use mendeley application. It is a current regulation in STKIP PGRI Sumbar in writing thesis.

They argued that home as a comfort place to do writing activity. They felt free when they wrote at home. Limited time in class does not allow students to pass the writing stage perfectly. This requires additional classes or writing activities outside the classroom (Sahih, 2014). Whereas, in delivering material teaching, they wanted that lecturer deliver by both of model, traditional and online. The need for students to go online is also illustrated by responding to asynchronous communication (no real time communication) and synchronous communication. Synchronous is other form to run classroom activity without physical presence (Mosier, Smith, Anderson, 2015). Meanwhile, asynchronous is to build sense of community in classroom and as tool in grup activity to collaborative skill. They agreed asynchronous as a way to communicate in online form since it is appropriate to writing collaboration (Khalil\&Ebner, 2017).

Revising and editing process, the students wanted to do together in and out of class. It will be called as peer review. It is a power to enhance students writing collaborative online. The lecturer can investigate student contribution and student activity in helping their friends writing (Bradley, Thouesny, 2017). In this communication, the students may revise, modify, their writing (Khalil\&Ebner, 2017). Last, students respon in collecting the task. All students agreed that by sending in online way is the effective way to collect the writing task. They do not print the task, so it will be less paper and less budget. They do not have to go to campus. It also save time.

Students respond above will be as a foundation to design instructional learning model for academic writing. As result, the teaching learning process will be divided into two form, 7 meetings for online and 9 meeting for face to face, as drawn below, 


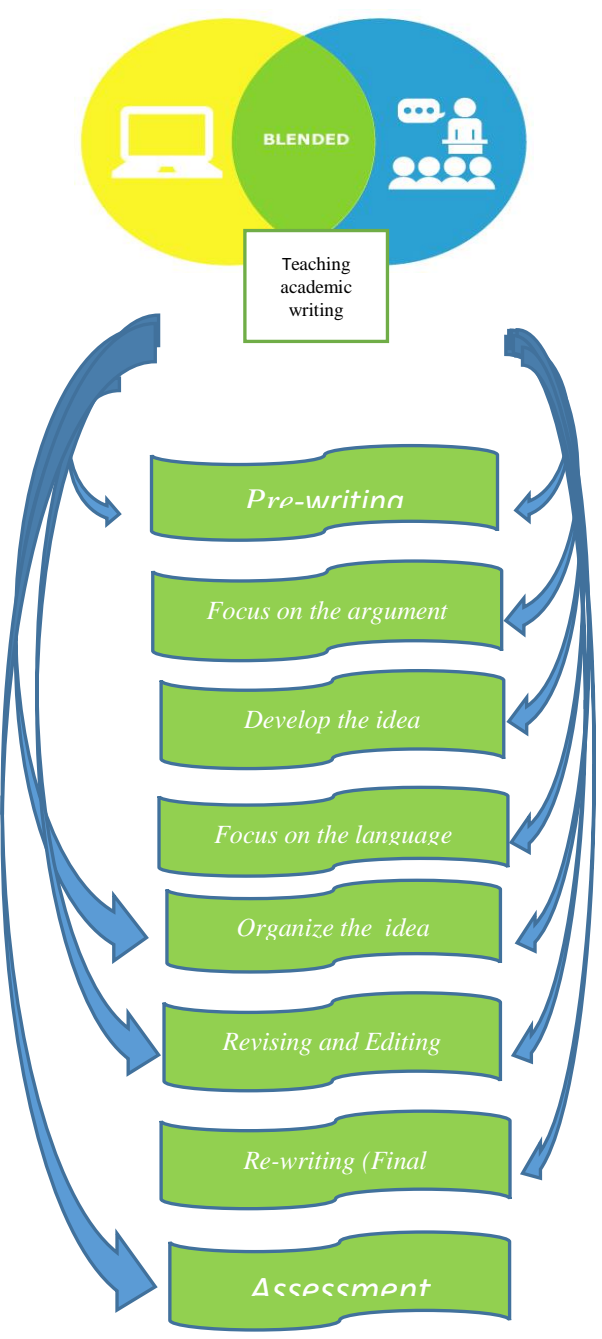

Figure 1. Academic Writing Instructional Design

The design show that, the 8 phrase should be followed by students in conducting writing academic. First phrase is pre-writing. It conducts into 2 meeting. There are some activities that student must do. They must know and deal with lecture contact. Then, the students and lecturer need to discuss about social text area of writing. The online activity involves downloading international article, then reviewing it and sending to lecturer by online tool. The third meeting is focus on the idea. It will be held in classroom once and discuss about how to differentiate between subject and thesis statement. After that, it continues by writing thesis statement. For the next material learning is develop the idea. This is a body of writing because the students will write content of writing. It begins by writing main idea of each paragraph. The students will do a research to find to support their argument. Then, they do not taking. In writing content, they also do paraphrase of sources, summarize, quotation, use table, graph and chart. The phrase will be hold in 3 times, 1 in classroom and 2 in online tool. After writing a content, they will focus on the language. It means, the check sentences, organize paragraph, coherent, and plagiarism. Then 4 meeting to organize the ideas, 2 in class and 2 in online tool. Next, revising and editing. It needs 3 meeting, 2 for classroom and 1 for online. Re-writing and final writing in class in 1 meeting. The last meeting is assessing the writing. Those are as pre design for academic writing.

\section{CONCLUSIONS}

The pre design of instructional learning for academic writing is the answer to the technology-based tertiary curriculum. Lecturer as educator must be responsive to changes in education and student needs. If we ignore what they need, they will not care about learning. Especially for academic writing, they must be serious about writing, because it involves the final task to complete their studies. By presenting online learning, we hope to give the widest possible space and time for them to write.

\section{ACKNOWLEDGMENTS}

Thank you for unknown reviewer who will review this article

\section{REFERENCES}

[1] Adas, D., \& Bakir, A. (2013). Writing Difficulties and New Solutions: Blended Learning as an Approach toImprove Writing Abilities. International Journal of Humanities and Social Science Vol. 3. www.ijhssnet.com

[2] Altay, I.F \& Altay (2019) A Review of Studies on Blended Learning in EFL Environment. International Journal Curriculum and Instrcution 11 (1) $125-140$

[3] Atmanegara, Y., Agustina, S., Tiara, D. (2013) Web-Based Resources In EFL Learning: An Enhancement of Students' Digital Literacy. Advanced in language and Literary Studies Vol 4 No 2

[4] Barker, P. (2012) On Being an Online Tutor: innovation in Education and Teaching International, Vol39, No.1, pp3-13

[5] Brandley. L, Thouesny. S (2017) Students Collaborative Peer Reviewing in an Online Writing Environment. Themesin Science \& Technology Education 10(2) 69-83

[6] Khalil, H., Ebner, M. (2017) Using Electronic Communication Tools in Online Group Activities to Develop Collaborative Learning Skill. Universal Journal of Educational Reseacrh 5(4):529-536

[7] Lalima\&Dangwal. K.L. (2017). Blended Learning: An Innovative Approach. Universal Journal of Educational Research 5(1):129-136

[8] Moser, S., Smith, P. (2015) Benefit of Synchronous Online Courses. ASCUE Proceedings 
[9] Plomp, T \& Nieeven, N. (2013) Educational Design Research. Netherlands. SLO

[10] Peretz, Arna (2005) "Teaching Scientific/Academic Writing in the Digital Age" The Electronic Journal of e-Learning Volume 3 Issue 1, pp 43-54, available online at www.ejel.org

[11]Zaki, A.A.,\& Yunus, M. Md.,(2015). Potential of Mobile Learning in Teaching of ESL Academic Writing. English Language Teaching; Vol. 8. URL: http://dx.doi.org/10.5539/elt.v8n6p11. 